RIEHTMANN

P U B I I S H I II G

\section{Research Article}

(C) 2020 Paola Bocale.

This is an open access article licensed under the Creative Commons Attribution-NonCommercial 4.0 International License (https://creativecommons.org/licenses/by-nc/4.o/)

\title{
Restorative Justice Principles and Practices and the Discourse of Respect: A Case Study of a Teacher in a Custodial Establishment for Young Offenders
}

\author{
Paola Bocale \\ Department of Human Sciences, Innovation and Territory, \\ Centre for Research on Minorities, University of Insubria, \\ Via Bossi 5, 22100 Como, Italy
}

Doi: 10.36941/mjss-2020-0o14

\section{Abstract}

This study aims to explore discourses of respect in the Education Department of a Young Offenders Institution (HMYOI X). The research builds upon the existing literature on the concept of respect both in restorative justice and in prisons to develop a deeper understanding of perspectives on respect in custodial education. More specifically, the study examines a self-narrative elicited from a teacher working in a YOI in England to investigate the discourses of respect which prevail in a custodial institution. The research findings provide a better understanding of the discourses and dynamics of respect within an educational custodial setting and of some of the problems and challenges that need to be addressed in enhancing and assessing the use of restorative justice in prisons.

Keywords: Restorative Justice, respect, young offenders, custody

After that episode in which he was punched by another prisoner he stopped coming out of his cell altogether because he had lost all the respect he had among his peers. A young offender at HMYOIX

\section{Introduction}

This study aims to explore discourses of respect in the Education Department of a Young Offenders Institution (HMYOI X). More specifically, the study was designed to capture how research participants - young offenders, teachers, staff and officers - understand respect, what respect feels like to them and what significance they give to it in interpersonal relationships in a YOI. The research builds upon the existing literature on the concept of respect both in restorative justice and in prisons to develop a deeper understanding of perspectives on respect in custodial education.

\section{Definitions and Key Concepts of Restorative Justice}

It is claimed (Van Ness \& Strong, 2014) that the expression 'restorative justice' was coined in 1977 by Albert Eglash who distinguished rehabilitative justice from retributive justice from restorative justice by which he meant restitution. By restitution, Eglash meant the possibility for offenders to make amends to those they had hurt (Mirsky, 2003) and thus implied a creative effort on the part of the offender to put right the harm done, a reparative, restorative act, something that restorative justice considers one of its main tenets. 
Other definitions of restorative justice emphasise other aspects. Marshall proposed a widely quoted definition according to which restorative justice is 'a process whereby all the parties with a stake in a particular offence come together to resolve collectively how to deal with the aftermath of the offence and its implications for the future' (Marshall, 1996: 37). The justice reform proposals, published on December $7^{\text {th }}, 2010$ in a Green Paper by Justice Secretary Kenneth Clarke, adopt a more victim-centered definition of restorative justice and stress its value in preventing reoffending (Clarke, 2010).

In reviewing literature on RJ some essential elements of the approach emerge. Among the most relevant there are the emphasis put on repairing the harm done by the offending by making offenders realize the impact on victims of their crime and asking them to try and put things right, as much as possible (Wallis, 2014; Walgrave, 2001); the opportunity it provides to victims and offenders to establish a dialogue to the benefit of all parties (Umbreit, Vos, Coates \& Brown, 2008); an effort to reintegrate or reconnect offenders as well as victims to their communities (Braithwaite 1989; Bazemore, 2005).

A more or less explicitly formulated assumption underlying descriptions of RJ is that it is a different, alternative form of justice which is opposed to the traditional, retributive ${ }^{1}$ model of justice. This opposition to the traditional model of justice is partly due to the fact that if long-established legal practices may satisfy the need of the State for the restoration of legality, they often leave the needs and requirements of the victims unsatisfied and can even be a cause of secondary victimization (Zehr, 1990).

There is, however, also another dimension of conflict and violence that RJ acknowledges and sets forth to repair and it is its relational aspect, the fact that what ultimately needs to be brought back, restored, are the essential, fragile bonds between human beings, their sense of belonging to a community, their possibility of believing in and coexisting in peaceful relationships (Zehr, 2002). It is in particular this latter dimension of RJ which is of most value in considering the implementation of restorative practices in YOIs because the reintegration into society, into their families and local communities, along with the possibility of living together peacefully while in custody are vital requirements for young offenders.

\subsection{Restorative Justice in practice}

Many Restorative Justice practices, such as VORPs, FGC and the Wagga Wagga model of conferencing, were established precisely for the purpose of handling youth crime. The fact that some of them have been adopted by schools seems to confirm their particular suitability for dealing with young people in education settings and encourages us to consider their appropriateness and practical feasibility in YOI Education.

\subsubsection{Victim-Offender Reconciliation Programs (VORP)}

All VORPs are based on meetings between offender and victim or between two conflicting parties facilitated by a mediator. The purpose of the meetings is overcoming the conflict and reaching a mutually satisfying reparation agreement. During the meeting the mediator brings the attention of the parties to three distinct aspects of the conflict:

a) What happened

b) What were the parties thinking at the time and what have they thought about since

c) What can be done to put things right

\footnotetext{
${ }^{1}$ The 'just deserts' principle is at the core of the retributive justice philosophy. Offenders have harmed society and they deserve to be punished according to the level of seriousness of their offences. The penalty imposed on offenders by the criminal justice system is meant to satisfy the demand of society and of victims, and to act as a deterrent to further reoffending (Capeheart \& Milovanovic, 2007).
} 
VORP encounters aim at including moments of narrative, mutual empathy and understanding and reparation (Van Ness, 2002).

\subsubsection{Family Group Conferencing (FGC)}

FGC involves not only victims and offenders but their respective families and/or communities as well, along with other individuals who may support the two parties, such as friends, teachers, peers and so on. A facilitator brings together the parties and their supporters to discuss the impact of the offence on their lives and how to put things right (Hess, 2009). Those who take part in a FGC are asked to support and keep an eye on the offender in order to make sure that the restorative program is successfully completed.

\subsubsection{Wagga Wagga model of conferencing}

This model of conferencing (named after the city of Wagga Waga in New South Wales, Australia ) is deeply influenced by Braithwaite's theory of reintegrative shaming (see below) in that it aims at inducing in offenders feelings of shame for what they perpetrated and in promoting their acceptance back into their communities (Braithwaite 2016; Braithwaite \& Petit, 2000).

On the basis of the Wagga Wagga model of conferencing the Thames Valley Police in the UK introduced conferences as a form of police cautioning in 1996 (McCold, 2001). Wagga Wagga style of conferencing has also been adopted in schools (Morris \& Maxwell, 2001).

\subsubsection{Restorative circles}

The arrangement of participants in circles is meant to create an atmosphere of respect and mutual comprehension and to favour sharing of information about the conflict (Dickson-Gilmore \& La Prairie, 2005). Restorative Justice circles developed along two models: healing circles and sentencing circles.

Healing circles tackle and settle conflicting situations with the aim of restoring all the parties involved in an offence (Dickson-Gilmore \& La Prairie, 2005). They aim at restoring not only individual cases of abuse but the overall sense of belonging to a healthy community. This form of community responsibility and control of the offender is believed to help offenders keep on track (McCold, 2001).

Sentencing circles are forums to discuss the offence and define the sentence with the community. They follow the model of discussion of Canadian native communities at which all the community members with a stake in a particular issue take part. There is a facilitator who mediates and guides the circle. The participants discuss issues related to the offence: how and why it happened, what is to be done to put things right and prevent similar offences happening in the future. Taking in consideration what has been said at the circle, a judge passes the sentence.

\section{$2.2 \quad$ RJ in youth justice}

In UK the Crime and Disorder Act 1998 aimed at giving RJ a major role in the administration of youth justice in the UK (Sherman \& Strang, 2007). New institutions, such as the Youth Offending Teams (YOTs), which are associations of education and health authorities, social service, probation and police were created for dealing with young offenders. The police was placed under a statutory duty to refer young people to a YOT for risk assessment and an eventual programme of intervention. The Act also set up a Youth Justice Board (YJB) to supervise the system. The introduction of referral orders and youth offender panels means that all first-time offenders under 18 years of age who plead guilty, no matter the seriousness of their offences, are referred to a youth offender panel, which also victims are encouraged to attend, to concord a programme to address their offending. The programme may 
involve forms of victim mediation and victim reparation.

\section{$2.3 \quad$ RJ in YOIs}

The Crime and Disorder Act 1998 requires YOTs to manage custodial sentences of young offenders in HM prisons (Sherman \& Strang, 2007). Through work carried out by YOTs, a number of YOIs are involved in RJ in the form of victim-offender mediation and conferencing. For example, Leeds and Torbay YOTs undertake cases where the offender is in a YOI (Liebmann, 2007).

RJ practices such as mediation and conferencing are also used to deal with conflicts arising inside prisons, for example before and after adjudications ${ }^{2}$. Some prisons, such as Grendon and Cornton Vale, have gone further and tried to embrace a whole-prison restorative approach. In these establishments, all or most staff are trained in RJ and incidents are dealt with in a restorative way (Newell, 2003).

However, on the overall it seems that there is little RJ intervention taking place in the juvenile secure estate in the UK. In 2004, the YJB for England and Wales funded a research project to establish the extent to which RJ was practiced within juvenile custodial and secure establishments (Curry et al., 2004). Out of 45 secure institutions, only six establishments stated that they used mediation at their establishment. The report identified some of the problems facing implementation of RJ practices in juvenile secure institutions. Along with a certain reluctance on the part of the institution to experiment with practices that challenge the way prisoners are commonly seen and managed in a custodial setting, there are also some objective difficulties relating to the fact that young offenders tend to be frequently moved around different institutions, which may happen to be quite distant from their homes and the places where the offences were committed. This makes victim-offender contact very unlikely to take place. The report also argued that most young offenders come from such traumatic experiences themselves that may be unable to empathize with their victims until they have dealt with their own issues. Although the 2004 YJB report is relatively old, it remains the most accurate and comprehensive source of information currently available on this topic.

\subsection{Restorative practices in educational settings}

Restorative practices are introduced in educational settings with the aim of creating a fair, safe and healthy environment for all members. This is the opinion of Morrison (2007) who recalls that RJ was first used in Australian schools for serious incidents which were dealt with using community accountability conferences based on the Wagga Wagga model of conferencing. In school conferencing the aim is to support those involved in a conflict by creating a circle of care that enables a frank and respectful dialogue to take place between the parties. Through this dialogue the parties can acknowledge what happened and look for the best way to repair the harm done.

$\mathrm{RJ}$ in schools cannot be limited to interventions in case of incidents, RJ "must touch the culture of the school as a whole" (Morrison, 2007: 66) through a continuum of practices. Morrison (2005) has developed a whole school model of RJ that features three levels of interventions in schools. The primary level, which involves all school members, aims at preventing the escalation of violence by developing students' skills in conflict resolution. The secondary level involves a small to medium school group which has become involved in a conflict situation which can be solved through healing circles. The tertiary level deals with serious incidents which have occurred within the school and involves the parties affected as well as a wider group of participants who all take part in a restorative conference.

For my research, one important element that emerges from the way RJ advocates restorative practices in schools is the need for them to be employed on a whole-school scale, something that is

\footnotetext{
${ }^{2}$ Adjudications are settlements of incidents arising in prisons. The offender appears before the governor who makes a judgement and establishes the penalty.
} 
even more important in educational settings in prisons, where comprehensiveness, consistency and uniformity in implementation of whatever practices should be an even stricter requirement due to security issues.

\section{Respect in Restorative Justice}

Restorative practices are underpinned by a set of values, such as equality, individual dignity, honesty, inclusion, tolerance, mutual comprehension and respect (Daly 2000; Pranis 2007). Respect is considered one of the core principles because Restorative Justice aims at restoring respect as a value and quality of relationships (Edgar \& Newell 2006). Howard Zehr, one of the key figures of Restorative Justice, believes that "respect is central in the message we must teach" (Zehr 1991:1). This conclusion is supported by other theorists who go as far as suggesting that the most realistic goal for Restorative Justice is to bring offenders and victims to respect each other (Van Ness and Strong 2014).

Respect is a core element in several restorative justice theories and practices. In one of the most significant works that outline his theory of restorative justice, Crime, Shame and Reintegration (1989), Braithwaite distinguishes between two different types of shaming. There is reintegrative shaming, which is a form of disapproval which coexists with a relationship of respect with the offender, whose casting is ultimately terminated. On the opposite side there is stigmatization which is humiliating shaming of the offender who is never reaccepted back into the community. One essential element of Braithwaite's theory is that building a relationship of respect with offenders contributes to their ultimate reintegration into society.

Morrison (2007) argues that in school conferencing the aim is to support those involved in a conflict by creating a circle of care that enables a frank and respectful dialogue to take place between the parties. Through this dialogue of respect the parties can acknowledge what happened and look for the best way to repair the harm done. Hopkins (2004) sees restorative practices in schools as based on a cluster of fundamental values such as openness, empowerment, inclusion, tolerance, integrity, coherence and respect.

However, despite the centrality and importance of discourses advocating respect in Restorative Justice the concept of respect has not yet been carefully studied or analysed. Mainly, the references to respect in restorative justice works are vague and consist of indefinite appeals to the duty of the parties involved to respect each other (see, for example, Zehr 2002: 36; Pranis, Stuart \& Wedge 2003: 107-108, 118; Umbreit \& Peterson Armour 2011: 103). Restorative Justice theorists and practitioners seem to have taken the concept of respect for granted and have ignored the depth and breadth of its definitions and implications. One of the goals of this research is thus to identify some of these definitions and begin to explore their implications for restorative justice.

\section{Respect in Custodial Establishments}

\subsection{Respect as one of the key dimensions to prison life}

Respect is a buzz word in young offenders institutions. It is undoubtedly an essential feature of relationships between teachers and offenders, as well as between officers and prisoners and among prisoners themselves. But what does respect mean in custodial establishments? Research on values in prisons for adults has highlighted the variety of meanings prisoners attach to the notion of respect. Crewe (2009) reports that in prisons, respect is often used to mean an attitude of caution towards someone perceived as dangerous because of their physical potential or social influence. In this case, to say that someone is respected means to acknowledge the potential for danger held by that individual. Respect can involve a component of admiration, reverence or esteem mixed with caution (Butler 2008). Young offenders talk of respecting murderers because killing someone involves crossing a line not everyone is able to or wants to cross. Another use of the term respect has to do with recognition of individuality. Prisoners talk about respecting officers who are good human 
beings, who treat them fairly, who don't abuse their position of power, who see prisoners as individuals (Butler \& Drake 2007). Finally, respect can be based on the positive appraisal of someone's qualities and thus mean admiration, regard and esteem for that person. I have often heard prisoners talking about respecting criminals who had been in prison for a very long time because they doubted whether they themselves could have endured the same.

\subsection{Respect and conflict in prisons}

Research on conflict in prisons has demonstrated that prisoners' feeling of respect has a strong impact on their relationships with other prisoners and prison staff and is one of the main causes of tension and conflict in prisons (Liebling 2004; Harvey 2007).

The link between lack of respect and anger has been investigated extensively (Butler 2008; Butler \& Drake 2007; Butler \& Maruna 2009; Butler \& Maruna 2016). One of the most common sources of anger has been identified in the feeling of having been treated disrespectfully. Empirical investigations revealed that disrespectful treatment is a determining factor of anger and aggression. It is argued that disrespectful treatment is interpreted as a sort of negative gift that demands repayment, i.e. retaliation (Miller 2001). These findings contribute to explaining confrontations in custodial establishments motivated by a perception of disrespect. Moreover, other lines of research have concluded that a common feature of those who show high levels of aggression is a low threshold for inferring disrespect from the actions of others (Blincoe \& Harris 2011). This is an important factor teachers and practitioners involved in restorative meetings should be aware of when bringing two conflicting parties together.

\section{Research Framework, Design and Methodology of the Study}

The aim of the study was to capture how research participants understand respect, what respect feels like to them and what significance they give to it in interpersonal relationships in a YOI. This suggested a case study as main methodology. The research questions were designed to identify the meanings teachers and staff working in custodial education attach to the concept of respect and to explore what implications discourses of respect have for the role of restorative practices in educational custodial institutions:

- How do the research participants in this study construct their discourse of respect?

- What multiple discourses of respect are at play and competing in the Education Department of a given YOI?

- What are the areas of communality and divergence in the different discourses of respect, and how can these be taken into account in order to promote a less conflictual environment in prison education?

The research was conducted in a Young Offenders Institution (HMYOIX) in England. The prison receives convicted young offenders from areas that include the ethnically quite diverse urban population of big cities such as London and Manchester, and the more homogeneous populations of Southern, East Midland, and Eastern England counties. Most young offenders are serving sentences of between one and three years for offences such as supplying drugs, possessing a prohibited weapon, burglary and robbery. However, some are also serving sentences as serious as murder and manslaughter.

Interviews were conducted with four teachers, one library employee and one former officer who had been working in HMYOIX until his retirement earlier in the year. In the interviews, participants were asked to recall and describe episodes in their work in the YOI when they felt that someone really deserved respect, episodes when they thought they had earned the respect of others and episodes when they experienced the respect of others. Interviews can be revealing not so much for the facts they contain but rather for the meanings the narrator attaches to such facts (Crewe 2009; Crewe 2014). The analysis of the research participants' narratives on episodes involving respect revealed what meaning participants give to respect in these experiences, how they think respect is 
shown for another person, what it represents for them. The next section will present a detailed analysis of an interview with one of the teachers and discuss it in the context of the role that restorative practices aiming at conflict resolution can play in prison.

\section{Respect for David, a Maths Teacher at HMYOIX}

David is in his late 40's, teaches Level 2 Maths, had a 20-year experience of teaching in comprehensive schools before coming to teach in HMYOIX.

\subsection{Theme 1: Respect is a complex of behaviours}

The first theme found in the interview with David is that respect is expressed in behavioural forms. David gives several examples of offenders' behaviours he considers inappropriate and unacceptable in an educational context, such as being overly familiar and overly causal with each other and with a teacher, calling a teacher by their first or shortened name, arriving late to a lesson and speaking when someone else is speaking. He makes the point that if you don't deal with how offenders behave in classroom early on you are going to end up with a much larger problem which may become out of control. David recounts a situation when one of his colleagues finished up losing control of the class because he didn't manage to deal with the issue of how students addressed him

\footnotetext{
we've got one teacher he's called ***er the teacher but they should be calling him $\mathrm{Mr}{ }^{* * * *}$ by his name and you can hear them shouting ${ }^{* * *} i e^{* * *} i e^{* * *} i e$ and they shouldn't be saying this to him certainly not by his first name and certainly not ${ }^{* * *}$ ie and unfortunately he's not actually dealt with it and so now you've got this complete lack of respect
}

The behavioural component of respect is also relevant the other way round, i.e. when teachers deal with students. David acknowledges that the way teachers treat offenders has to be appropriate to their age and maturity. Young offenders are very sensitive to actual or perceived disrespect and deeply resent any form of treatment that could cause loss of face or offend their dignity

I think they see respect as being treated with in a mature adult manner not being spoken down to not being given short sharp instructions [...] we often bark commands to young offenders and they see that as being disrespectful to them

The forms or ways by which both students and teachers convey respect for each other emerge thus as being very important in shaping the classroom environment and influencing attitudes and feelings among students and teachers.

\subsection{Theme 2: Respect involves egalitarian and non-hierarchical interpersonal relationships}

The second theme identified in this interview is that respect involves egalitarian and non-hierarchical interpersonal relationships. It is interesting that this aspect of respect developed through David bringing examples of what he feels is disrespectful treatment of the Education management towards the teachers. Managers allow themselves to behave in a way teachers are not allowed to

$$
\begin{aligned}
& \text { the nature of the management system now is you do get a lot of managers who don't spend any great } \\
& \text { amount of time speaking to their staff in a particularly nice way it's just sharp and it's almost as if they } \\
& \text { are sort of saying there's an hierarchy in the Education Department we are the sort of the senior team } \\
& \text { and therefore you have to do what we say and we can do all }
\end{aligned}
$$

David refers to the managers' sharp way of dealing with staff and it is interesting to remember that in a passage analysed above he admitted addressing offenders in a short and sharp manner which could be perceived as aggressive and lead to confrontations. 
Another example of management's disrespectful behaviour is arriving late at meeting and then dictating their own pace

we as a staff do feel that that's quite disrespectful that you've got your teaching staff waiting for you in the staffroom and the meeting is supposed to start at a quarter past eight and here they arrive at 25 past and as soon as they walk in they go 'right let's start' and you can see people instantly 'what!'

We saw earlier on that David disapproves of offenders arriving late for lessons and in the above extract we find managers, who are at the opposite end of the prison hierarchy, behaving similarly towards teaching staff.

The importance of building a dialogue among conflicting parties is emphasized in restorative justice and it comes to no surprise then that David views restorative interventions as a positive step towards the rehabilitation of prisoners

I think it [i.e. Restorative Justice] has a lot of power to work in certain situations and obviously getting somebody to acknowledge the importance of their crimes is part way towards getting them to at least try not to do that again [...]

David emphasises the importance of discussing the impact of the prisoners' actions and behaviour on their own and other lives. Moreover, he stresses the value of fostering a democratic environment in the classroom by giving a voice and listening to the views of individuals who come from a background of constant devaluation, demotivation and degradation.

I tend to have a lot of discussions with the people that I teach on whatever crops up [...] and I think that goes a long way because in terms of respect it's showing that you want to hear their opinion and that it has some value and too often they've had a background which says'you're hopeless you'll only end up in prison so to have somebody saying 'tell me what you think' is quite valuable to them

David believes that it is by listening closely to offenders and understanding what is at stake for them that changes can be made that have meaningful impact on their lives. He concludes stressing that rules should apply uniformly to all if you want a respectful environment in your workplace. What emerges from David's line of thought is that respect involves an egalitarian and nonhierarchical environment where human behaviour and relations among people are based on a common set of values, norms and obligations everybody is expected to embrace and share: "you can't have respect if you don't see people actually applying the same sort of values and culture".

\subsection{Theme 3: Respect is a reciprocal act}

The last theme running through the interview with David touches on the reciprocal component of respect. David acknowledges that an overly aggressive and assertive behaviour on the part of the teachers may trigger a confrontation with the students who in return are not respectful back

we're a bit disrespectful to the students particularly when they're in the corridors and we're told by the prison management that the offenders have got to do certain things [...] you then get the confrontation when they are later they are not respectful back

Lack of reciprocal respect between a teacher and a student damages not only their relationship, but the overall climate of the classroom because the other students see the confrontation as a manifestation of poor classroom control and management

in your lessons there's wriggle room and that wriggle room on minor things actually ends up with the student being disrespectful to a teacher and a teacher probably in turn being overly assertive or unpleasant to a student who they perceive has been disrespectful and before you know it you've lost relationship with that student you've lost the group because the rest of the students in your group are 
seeing your teaching has been inappropriate and it's lack of respect

Confrontational issues with students are no-win situations, they are not conducive to respect because, argues David, they only trigger further disrespect and an overall climate of hostility and distrust in the classroom. Moreover, he notes that respect and disrespect seem to have a catching quality that grows and grows. If young offenders have had issues in one lesson they'll carry their negative behaviour and disruptive attitude over into the next lessons until it escalates into major conflicts of open arguments or physical fights

if they've had confrontations in one lesson they'll come to your lesson in the mood for a confrontation and before you know it you can be picking up problems that happened sort of two or three lessons earlier

Conversely, if the overall climate is one of respect on both sides the learning environment will be one of non-threatening trust and support. David insists on the necessity of having an overall atmosphere of mutual respect if you want restorative interventions to be successful. He makes the point that restorative justice cannot work in isolation if it wants to be effective

if you are striving with a classroom in the prison where it's a free flaw and people are just messing about and are up to no good and there's no rules then it [i.e. Restorative Justice] won't work because in reality nobody is going to respect this idea [and they'll just think] well he did it to me I'll do it to him

\subsection{Conceptual categories emerged from the data}

The first conceptual category underlying this data is respect as a complex of learned patterns of behaviour. David believes that there is a complex of behaviours recognized collectively by members of a given society as respectful or disrespectful. Whether it is managers or offenders, teachers or officers, there is a certain core of practices and actions that are consistently associated with respect and are expected of everyone. These behaviours conform to the expectations of the community to which individuals belong and are required of everyone in that group.

This brings about the second category emerged from the data, respect as equality. In a respectful environment, there is an implicit agreement that everyone is considered equal and is thus entitled to equal treatment, including equal rights, privileges, opportunities and consideration. Lack of equal treatment triggers feelings of anger and resentment, which can then lead to acts of confrontation and physical and emotional violence.

Finally, the last category underlying David's talk is respect as reciprocity. Respect is reciprocal because goes in both directions and is felt by both sides. Moreover, the reciprocal nature of respect probably contributes to making it contagious. Respect and disrespect spread easily throughout a community and well beyond the original action or interaction, impacting other actions/interactions and encouraging other respect or disrespect.

\subsection{David's discourse of respect}

David's discourse of respect is structured by his account of episodes involving behavioural forms of respect, with words like 'behave', 'behaviour', 'treat', 'do' and 'deal with' echoing like a chorus throughout his account

they don't see their behaviour as being any more they see themselves as being the victims and then therefore if somebody else is the victim then they don't see it as being wrong [...] in our prison if you've got this undisciplined behaviour going on then you've never going to get restorative justice working because they're going to say well hang about we don't see that going around us so we don't see that's wrong or certainly it's normal for here so therefore what's wrong with it they're not going to change

David experiences respect as the power of adopting certain forms of behaviour which 
correspond to certain norms and values. His narrative of episodes of respect and disrespect include interactions where although different social actors are involved, the same patterns of behaviour are displayed. The disrespectful behaviour of managers matches the disrespectful behaviour of offenders, the disrespectful tone of teachers reflects that of managers, the disrespectful attitude of offenders is mirrored in that of some teachers and ultimately respect and disrespect emerge in David's account as a complex symphony of practices and patterns that repeat themselves over and over on different scales and on different levels. Those who share a common culture display certain common modes of behaviour which, says David, are internalized by individuals early in life. Respect is acquired at home and then transferred to broader life situations and actions "it [respect] comes from the home the amount of time their parents put into them spent with them or get their advice at home transfers to life". David believes that certain behaviours which are characteristic of the members of a given social and cultural system are absorbed by individuals in the course of their development and socialization "your teaching and learning actually is going to be the behaviour of your inmates".

Finally, David insists on the need for teachers to instil certain values and attitudes that will then result in a certain behaviour on the part of the young offenders. Respect as a value can be instilled and result in a need for respect and in a respectful behaviour

in any institution if you've got the right environment and the right culture and the right values and we are going to apply these values all way through you'll get an environment of respect.

\section{Respect and Restorative Justice in Prison. Discussion.}

The review of restorative justice principles and practices showed how respect is considered one of the core principles because RJ aims both at restoring respect as a value and quality of relationships and at bringing offenders and victims to respect and identify with each other. As the quotation which opens this study shows, respect is a word used with extreme frequency by young offenders, just as it is by officers and prison civilian staff, including teachers working in the prison education department. Respect seems to be central to the young male image, and this is intensified in the prison setting. If you ain't got respect, you got nothing Miss the author of this paper was told by one young offender and David confirmed the extreme importance of respect for young offenders when he said that the offenders are very keen on being respected in fact one of the things they'd say quite a lot is are you dissing me which is disrespecting this idea of disrespect is quite important to them.

Respect as an unconditional human entitlement points to something individuals are owed simply because they are human beings. The implication of the concept that respect is unconditional, is that respect is not earned. However, the emphasis in modern society on earning respect is extremely strong throughout Western culture. A Google search with the key words "to earn respect" brought up about 1.230.00o results in a Google search at the time of writing. In prison, often and again officers repeat the mantra 'respect you earn'. Contrary to the notion of respect as a fundamental right and entitlement, earned respect implies an appraisal process that involves people assessing someone's value on the basis of certain parameters. The question then arises how much is unconditional respect recognized in the practice of the prison system, as well as in other social structures and institutions.

Butler (2008) notes that prison staff find it difficult to feel respect for prisoners because these are individuals who have officially lost that same respect in society. Moreover, it is argued that prison by its very nature makes it difficult for those in charge to feel respect for their passive and not autonomous subjects. Butler \& Drake (2007), who conducted research on the concept of respect in adult prisons, note that the realities of the prison system, such as the authoritarian environment, the status of prisoners as criminals, the role of officers as wardens, and the treatment of prisoners as passive recipients of power make it impossible for offenders to earn the respect of the officers. These considerations are important in setting up and conducting restorative meetings for incidents occurred between young offenders and prison uniformed staff. If one of the main goals in restorative meetings is to bring the two parties to respect each other (Van Ness and Strong 2014), it will have to be taken into 
account that officers may interpret respect primarily as mandated, based on compliance and obedience.

De Cremer \& Tyler (2005) remind us that there is an important contextual factor affecting the perception of respect and that is the audience, who is around when an interaction takes place. The same forms of behaviour, the same language and attitudes are going to be perceived in quite different ways whether or not a public is present. For example, I have seen that a young offender who is scolded by a teacher or an officer in front of other young prisoners feels more disrespected than when he is criticized in private, because the public dimension of the criticism will increase the threat to the boy's 'face' and status among his peers. This is confirmed by David, who resented an officer who had dealt carelessly with a prisoner in front of other prisoners.

The response to an act perceived as disrespectful also varies in accordance with the nature of the audience (Simon \& Stürmer 2005). If the audience expects some form of retaliation for disrespectful treatment it is likely that the affected party will retaliate to preserve his image in the eyes of the others. I once witnessed an episode when one young offender who had had a conflict in a classroom was being taken away by three officers. He wasn't handcuffed or physically restrained by the officers, who were escorting him back to his wing. As this young person was walking past the library windows, where a group of other offenders were watching the scene, he suddenly kicked off and started shouting and punching the officers who then put him on the ground and restrained him. When I asked the offenders why the prisoner had reacted in that way they said it was because they were there watching and he didn't want to be seen as giving in to the officers. Restorative practitioners should take into account the contextual factors that affect respect when addressing conflict based on issues of disrespect and in preventing similar incidents.

In conclusion, this research has provided a better understanding of the discourses and dynamics of respect within an educational custodial setting and of some of the problems and challenges that need to be addressed in enhancing and assessing the use of restorative justice in prisons.

\section{References}

Bazemore, G. (2005). Whom and how do we reintegrate? Finding community in restorative justice. Criminology and Public Policy, 4, 901-918. doi.org/10.1111/j.1745-9133.2005.00011.x

Blincoe, S. \& Harris, M. (2011). Status and inclusion, anger and sadness: Gendered responses to disrespect. European Journal of Social Psychology, 41(4), 508-517. doi.org/10.1002/ejsp.811

Braithwaite, J. (1989). Crime, Shame and Reintegration. Cambridge: CUP.

Braithwaite, J. (2016). Learning to scale up restorative justice. In Clamp, K. (ed.), Restorative Justice in Transitional Settings. Abingdon: Routledge, pp. 173-189.

Braithwaite, J. \& Petit, P. (2000). Republicanism and Restorative Justice: An Explanatory and Normative Connection. In H. Strang \& J. Braithwaite (Eds.), Restorative Justice: Philosophy to Practice (150-165). Aldershot: Ashgate.

Butler, M. (2008). What are you looking at? Prisoner confrontations and the search for respect. The British Journal of Criminology, 48, 856-873. doi.org/10.1093/bjc/azno53

Butler, M. and Drake, D.H. (2007). Reconsidering respect: its role in Her Majesty's Prison Service. The Howard Journal of Criminal Justice, 46(2), 115-127. doi.org/10.1111/j.1468-2311.2007.0046o.x

Butler, M. and Maruna, S. (2009). The impact of disrespect on prisoners' aggression: outcomes of experimentally inducing violence-supportive cognition. Psychology, Crime and Law, 15(2-3), 235-250. doi.org/10.1080/10683160802190970

Butler, M. and Maruna, S. (2016). Rethinking Prison Disciplinary Processes: A Potential Future for Restorative Justice. Victims and offenders, 11(1), 126-148. doi.org/10.1080/15564886.2015.1117997

Clarke, K. (2010). Breaking the cycle: effective punishment, rehabilitation and sentencing of offenders. Green Paper by Justice Secretary Kenneth Clarke published on $7^{\text {th }}$ December 2010. Retrieved from http://www.justice.gov.uk/consultations/breaking-cycle-o71210.htm

Crewe, B. (2009). The prisoner society: power, adaptation, and social life in an English prison. Oxford: Oxford University Press.

Crewe, B. (2014). Not Looking Hard Enough: Masculinity, Emotion, and Prison Research. Qualitative Inquiry 20(4), 392-403. doi.org/10.1177/1077800413515829 
Curry, D., Knight, V., Owens-Rawle, D., Patel, S., Semenchuk, M. and Williams, B. (2004), Restorative Justice in the Juvenile Secure Estate, YJB Retrieved from http://www.yjb.gov.uk/publications/Resources/Downloads /RJcustodyfull.pdf

Daly, K. (2000). Restorative Justice in Diverse and Unequal Societies. In A.J. Goldsmith and M. Israel (Eds.), Criminal Justice in Diverse Communities (167-191), Annandale NSW, Australia: The Federation Press.

de Cremer, D. and Tyler, T.R. (2005). Am I Respected or Not? Inclusion and Reputation as Issues in Group Membership. Social Justice Research, 18(2), 121-153. doi.org/10.1007/s11211-005-7366-3

Dickson- Gilmore, J. \& La Prairie, C. (2005). Will the Circle be Unbroken?: Aboriginal Communities, Restorative Justice and the Challenges of Conflict and Change. Toronto: University of Toronto Press.

Edgar, K. \& Newell, T. (2006). Restorative Justice in Prisons. A guide to making it happen. Winchester: Waterside Press.

Harvey, J. (2007). Young men in prison: surviving and adapting to life inside. Cullompton: Willan.

Hess, K.M. (2009). Juvenile Justice ( $5^{\text {th }}$ ed.). Belmont, California: Wadsworth.

Hopkins, B. (2004). Just schools: a whole school approach to restorative justice. London: Jessica Kingsley.

Liebling, A. (2004). Prisons and their moral performance: a study of values, quality and prison life. Oxford: Oxford University Press.

Liebmann, M. (2007). Restorative Justice. How it works. London and Philadelphia: Jessica Kingsley.

Marshall, T.F. (1996). The Evolution of Restorative Justice in Britain. European Journal on Criminal Policy and Research, 4, 21-43.

McCold, P. (2001). Primary Restorative Justice Practices. In A. Morris \& G. Maxwell (Eds.), Restorative Justice for Juvenile: conferencing, mediation and circles (pp. 41-58). Oxford: Hart.

Miller, D.T. (2001). Disrespect and the experience of injustice. Annual Review of Psychology, 52, 527-553. doi.org/10.1146/annurev.psych.52.1.527

Mirsky, L. (2003). Albert Eglash and Creative Restitution: A precursor to Restorative Practices. Restorative Practices E-Forum, International Institute for Restorative Practices. Retrieved from http://www.iirp.org/library/eglash.html.

Morris, A. \& Maxwell, G. (2001). Restorative Justice for Juveniles: conferencing, mediation and circles. Oxford: Hart.

Morrison, B. (2005). Restorative Justice in Schools. In E. Elliott, R. Macaire Gordon (Eds.), New Directions in Restorative Justice: Issues, Practice, Evaluation (pp. 26-52). Cullompton, Devon: Willan Publishing.

Morrison, B. (2007). Restoring safe school communities: A whole school response to bullying, violence and alienation. Annandale NSW, Australia: The Federation Press.

Newell, T. (2003, June 20). Building restorative prisons. Restorative Practices EForum. Retrieved from http://www.realjustice.org/uploads/article_pdfs/newell.pdf

Pranis, K. (2007). Restorative values. In G. Johnstone and D. W. Van Ness (Eds.), Handbook of Restorative Justice (pp. 59-74). Cullompton, Devon: Willan Publishing.

Pranis, K., Stuart, B. \& Wedge, M. (2003). Peacemaking circles: from crime to community. St Paul, Minnesota: Living Justice Press.

Sherman, L.W. \& Strang, H, 2007. Restorative Justice: the Evidence. London: Smith Institute. Retrieved from http://www.esmeefairbairn.org.uk/docs/RJ_full_report.pdf

Simon, B. and Stürmer, S. (2005). In search of the active ingredient of respect: a closer look at the role of acceptance. European Journal of Social Psychology, 35, 809-818. doi.org/10.1002/ejsp.272

Umbreit, M.S., Vos, B., Coates, R.B. \& Brown, K. (2008). Victim-Offender Dialogue in violent cases: A multisided study in the United States. In E. Van der Spuy, S. Parmentier, A. Dissel (Eds.), Restorative justice: politics, policies and prospects (pp. 22-39). Alphen aan den Rijn: Kluwer.

Umbreit, M. \& Peterson Armour, M. (2011). Restorative Justice Dialogue: An Essential Guide for Research and Practice. New York: Springer.

Van Ness, D.W. (2002). The Shape of Things to Come: A Framework for Thinking about a Restorative Justice System. In E.G.M. Weitekamp \& H.-J. Kerner (Eds.), Restorative Justice: Theoretical Foundations (pp. 1-20). Cullompton, Devon: Willan Publishing.

Van Ness, D.W. and Strong, K.H. (2014). Restoring Justice $\left(5^{\text {th }}\right.$ ed.). New York: Routledge.

Walgrave, L. (2001). On Restoration and Punishment: Favourable Similarities and Fortunate Differences. In A. Morris and G. Maxwell (Eds.), Restorative Justice for Juveniles. Conferencing, Mediation and Circles (pp. 1740). Oxford: Hart Publishing.

Wallis, P. (2014). Understanding restorative justice: How empathy can close the gap created by crime. Bristol: Policy Press.

Zehr, H. (1990). Changing Lenses: A New Focus for Crime and Justice. Scottsdale, PA: Herald Press.

Zehr, H. (2002). The little book of restorative justice. Intercourse, PA: Good Books. 


\section{Appendix}

Table 1: Construction of theme Respect is a complex of behaviours

\begin{tabular}{|c|c|c|}
\hline Text from David's interview & Concepts & Theme \\
\hline $\begin{array}{l}\text { in the classroom we quite often find students who ehmm are a bit overly familiar and } \\
\text { overly causal with each other and sometimes some of the things that they'll say they'll } \\
\text { sort of say the same sort of things they may say in the wings but sort of in the wings } \\
\text { you get some swearing and so on and we don't like any of that and sometimes they are } \\
\text { overly familiar with each other and that and this kind of a bit of a lack of respect but } \\
\text { certainly in the classroom we we as teachers would expect them to be in terms of } \\
\text { respect polite courteous and actually always always speak to you in a certain manner } \\
\text { and not be overly familiar }\end{array}$ & $\begin{array}{l}\text { being overly familiar and } \\
\text { overly causal with each } \\
\text { other and with a teacher } \\
\text { is not respectful }\end{array}$ & \multirow{5}{*}{$\begin{array}{l}\text { Respect is a } \\
\text { complex of } \\
\text { behaviours }\end{array}$} \\
\hline $\begin{array}{l}\text { we've got one teacher in Education now who actually he's called }{ }^{* * *} \text { er the teacher but } \\
\text { they should be calling him Mr }{ }^{* * *} \text { by his name and you go in there and you can hear } \\
\text { shouting because he's in the classroom next to mine and you can hear them shouting } \\
{ }^{* * *} \text { ie }{ }^{* * *} \text { ie }{ }^{* * *} \text { ie and so on of course you go into the room and they shouldn't be saying } \\
\text { this to him certainly not by his first name and certainly not }{ }^{* *} \text { ie and so on and you } \\
\text { know you can see these young offenders actually being quite rude by calling him } \\
\text { names and shouting things out and making making slight comments and } \\
\text { unfortunately he's not he's not actually dealt with it and so now you've got this } \\
\text { complete lack of respect so on so if you start off and someone is saying oh oh Paola } \\
\text { and before you know it's Paola Paola and then because in prison it should be you know } \\
\text { it should be you know Ms Bocale rather than that }\end{array}$ & $\begin{array}{l}\text { the way prisoners speak } \\
\text { to each other and to } \\
\text { teachers reflects the level } \\
\text { of respect they have for } \\
\text { that individual } \\
\text { respect is expressed in } \\
\text { behavioural forms }\end{array}$ & \\
\hline $\begin{array}{l}\text { also the way the way they behave I mean we we for example I don't think it's respectful } \\
\text { if a student is arriving to your lesson late I don't think it's respectful if a student is you } \\
\text { know in the lesson if they are if they're speaking when you are speaking or if they're } \\
\text { speaking when somebody else is speaking so in terms of that sort of respect is how } \\
\text { they are supposed to behave }\end{array}$ & $\begin{array}{l}\text { arriving late to a lesson } \\
\text { and speaking when } \\
\text { someone's speaking is } \\
\text { non respectful behaviour }\end{array}$ & \\
\hline $\begin{array}{l}\text { the way you speak not not not actually treating them as young adults rather than a } \\
\text { child you're just saying 'do this do that stop talking stop' and I think we often bark } \\
\text { commands to young offenders and they see that as being disrespectful to them }\end{array}$ & $\begin{array}{l}\text { the way you speak to } \\
\text { young offenders has to be } \\
\text { appropriate to their age }\end{array}$ & \\
\hline $\begin{array}{l}\text { I think the offenders are very keen to very keen on on you know on being respected in } \\
\text { fact one of the things they'd say or they used to say quite a lot was you know are you } \\
\text { dissing me or some which is disrespecting this this this idea of disrespect is is quite } \\
\text { important to them so they they like they like to feel that you are treating them in I } \\
\text { think they see respect as being treated with in a mature adult manner not being } \\
\text { spoken down to not not not not being not being given short sharp instructions being } \\
\text { you know constantly told what to do as if they've got no no opinion and I think } \\
\text { sometimes the way and the way you speak not not not actually treating them as young } \\
\text { adults rather than a child you're just saying 'do this do that stop talking stop' and I } \\
\text { think we often bark commands to young offenders and they see that as being } \\
\text { disrespectful to them }\end{array}$ & $\begin{array}{l}\text { young offenders want to } \\
\text { be treated in a certain } \\
\text { way in order to feel they } \\
\text { are respected }\end{array}$ & \\
\hline $\begin{array}{l}\text { you get this sort of behaviour they say these things to you as a teacher that you can see } \\
\text { they they might be saying to their inmates on the wing you know when when they are } \\
\text { sort of being a bit you know get this do this well and you actually think it's a different } \\
\text { place }\end{array}$ & $\begin{array}{l}\text { respecting a teacher } \\
\text { involves behaving with } \\
\text { them in a certain way }\end{array}$ & \\
\hline
\end{tabular}

Table 2: Construction of theme Respect involves egalitarian and non-hierarchical interpersonal relationships

\begin{tabular}{l}
\hline Text from David's interview \\
I think that the nature of the management system now is you do get a lot of \\
managers who are I think quite you know who who sort of who they don't spend \\
any great amount of time speaking to their staff in a particularly nice way I think \\
it's quite it's just sharp and it's almost as if they are sort of saying there's an \\
hierarchy in the Education Department we we we are the sort of the senior team \\
and therefore what you know you have to do what we say and we can do all \\
\hline we as a staff do feel that that's quite disrespectful you know that you've got your \\
teaching staff waiting for you in the staffroom and the meeting is supposed to start \\
at a quarter past eight and here they arrive at 25 past and you are all waiting and as \\
soon as they walk in they go 'right let's start' and you can see people instantly [deep \\
breath] 'what!' ehmm so I think I don't perceive our management you know when \\
they are speaking to the whole staff as being particularly respectful
\end{tabular}

\begin{tabular}{|l|c|}
\hline $\begin{array}{l}\text { Concepts } \\
\text { managers allow } \\
\text { themselves to behave in } \\
\text { allowed to }\end{array}$ & Theme \\
\hline $\begin{array}{l}\text { it is disrespectful to } \\
\text { have people waiting for } \\
\text { you and then dictating } \\
\text { your own pace }\end{array}$ & $\begin{array}{c}\text { Respect involves } \\
\text { hierarchical } \\
\text { interpersonal } \\
\text { relationships }\end{array}$ \\
\end{tabular}




\section{Text from David's interview}

I've waited two and half weeks to have my window replaced because I had to wait for the guy to come on a Saturday morning because I couldn't I can't do it during the course of the school day because I can't get time off yet I know the Head only you know last year went home and stayed worked from home so he could be there for a washing machine delivery I can't do that you know and I think sometimes we see we see this as being quite disrespectful when you have one rule for one set of people and one rule for the other in Education you can have only two members of teaching staff on a course right? but the number of times that the senior management they are not in the department right? and you think hang about why why is that this rule doesn't apply to everybody they're part of the staff if there's three people then they shouldn't go but they do so I think they seem we find out that's quite disrespectful that you know you've got you're answerable to them they just sort of cover for each other you can't have respect if you don't see people you know with the same you know actually applying the same sort of values and culture

\begin{tabular}{|l|l|}
\hline Concepts & Theme \\
\hline $\begin{array}{l}\text { it is disrespectful to } \\
\text { have one set of rules for } \\
\text { one group of people and } \\
\text { another one for another } \\
\text { group }\end{array}$ & \\
\hline $\begin{array}{l}\text { the management team } \\
\text { allow themselves a } \\
\text { privileged behaviour }\end{array}$ & \\
\hline $\begin{array}{l}\text { the same set of values } \\
\text { has to be applied by } \\
\text { everyone }\end{array}$ & \\
\hline
\end{tabular}

Table 3: Construction of theme Respect is a reciprocal act

\begin{tabular}{|c|c|c|}
\hline Text from David's interview & Concepts & Theme \\
\hline $\begin{array}{l}\text { quite often we we're a bit disrespectful to the students particularly when when they're in } \\
\text { the corridors and we're told by the the prison management that the offenders have got to } \\
\text { do certain things but of course what happens is you see a prisoner in the corridor and } \\
\text { rather than saying 'could you please go to your classroom' or so you end up end up saying } \\
\text { 'go to your classroom or you'll get a negative IEP' and then you're being quite short and } \\
\text { sharp and even sometimes you know you think you're being assertive but you are } \\
\text { probably being a little bit overly aggressive and of course you then have you then get the } \\
\text { confrontation when they are later they are not respectful back and then then it escalates }\end{array}$ & $\begin{array}{l}\text { the way teachers address } \\
\text { young offenders can } \\
\text { trigger an aggressive } \\
\text { response }\end{array}$ & \multirow{5}{*}{$\begin{array}{l}\text { Respect is a } \\
\text { reciprocal } \\
\text { act }\end{array}$} \\
\hline $\begin{array}{l}\text { you don't treat with respect because their their behaviour is such that you actually end up } \\
\text { being quite quite unpleasant people and and and therefore disrespectful to them because } \\
\text { they're not behaving in a certain way }\end{array}$ & $\begin{array}{l}\text { teachers are } \\
\text { disrespectful to } \\
\text { offenders as a response } \\
\text { to the way the latter } \\
\text { behave }\end{array}$ & \\
\hline $\begin{array}{l}\text { in your lessons you you know there's room for there's wriggle room right? and that } \\
\text { wriggle room on minor things actually ends up with the young offender the student being } \\
\text { disrespectful to a teacher and a teacher probably in turn being overly overly assertive or } \\
\text { you know unpleasant to a student who they perceive has been disrespectful and before } \\
\text { you know it you've lost relationship with that student you've lost the group because the } \\
\text { rest of the students in your group are seeing your teaching has been inappropriate or } \\
\text { saying things you know and you know and it's lack of respect right? }\end{array}$ & $\begin{array}{l}\text { students' behaviour } \\
\text { triggers a similar } \\
\text { behaviour on the part of } \\
\text { the teachers }\end{array}$ & \\
\hline $\begin{array}{l}\text { I think when you've got this sort of this boisterous chaos where you know people get } \\
\text { people have been barged into have been they're just passing on the same sort of treatment } \\
\text { on somebody else they don't see that as being they don't see their behaviour as being any } \\
\text { more they see themselves as being the victims and then therefore if somebody else is the } \\
\text { victim then they don't see it as being wrong }\end{array}$ & $\begin{array}{l}\text { disrespectful behaviour } \\
\text { catches up }\end{array}$ & \\
\hline $\begin{array}{l}\text { if they've had confrontations in one lesson they'll come to your lesson in the in the mood } \\
\text { for a confrontation and before you know it you know you you you can you can be picking } \\
\text { you can be picking up problems that happened sort of two or three lessons earlier you } \\
\text { know and these young prisoners then you know they lose their temper and it carries into } \\
\text { that }\end{array}$ & $\begin{array}{l}\text { disrespect as a chain of } \\
\text { interconnected } \\
\text { behaviours that trigger } \\
\text { each other }\end{array}$ & \\
\hline
\end{tabular}

